\title{
Acute Diarrhea Etiology in Young Children and Adults in the Republic of Maldives-A Point Prevalence Study
}

\author{
Abdul A. Yoosuf ${ }^{1,2}$, Ladaporn Bodhidatta ${ }^{3}$, Siriporn Sornsakrin ${ }^{3}$, Fathimath I. Manik ${ }^{1,2}$, \\ Shah Saeed", Mohamed Hassan", Carl J. Mason³ \\ ${ }^{1}$ Indira Gandhi Memorial Hospital, Male, Republic of Maldives \\ ${ }^{2}$ Azmi-Naeem Medical and Diagnostic Centre, Male, Republic of Maldives \\ ${ }^{3}$ Armed Forces Research Institute of Medical Sciences, Bangkok, Thailand \\ ${ }^{4}$ Hithadhoo Regional Hospital, Seenu Atoll, Republic of Maldives \\ ${ }^{5}$ Kulhudhuffushi Regional Hospital, Haa Dhaalu Atoll, Republic of Maldives \\ Email: ladapornb@afrims.org
}

Received 21 August 2015; accepted 1 December 2015; published 4 December 2015

Copyright (C) 2015 by authors and Scientific Research Publishing Inc.

This work is licensed under the Creative Commons Attribution International License (CC BY).

http://creativecommons.org/licenses/by/4.0/

c) (†) Open Access

\section{Abstract}

Introduction: Despite its recent status of middle-income country in WHO's South-East Asia Region, diarrhea remains an important yet unresearched public health issue in the Republic of Maldives. Methodology: We conducted a one-month cross-sectional study in children and adults with acute diarrhea at three regional hospitals in Maldives in August-September 2007 to investigate the pointprevalence of diarrhea etiologic agents. Enteric Bacteria was identified by a standard microbiology technique and isolates were submitted for antimicrobial susceptibility testing. Rotavirus, astrovirus and adenovirus were detected by enzyme-linked immunosorbent assays (ELISA). Realtime reverse-transcription polymerase chain reaction (RT-PCR) was used to test for norovirus. Results: We enrolled 73 children and 57 adults with acute diarrhea. The most common pathogens detected in children were norovirus $(43 \%)$ and rotavirus $(18 \%)$. Vibrio parahaemolyticus $(18 \%)$ and rotavirus $(17 \%)$ were the most common pathogens found in adults. Multiple and mixed infections were common. All noroviruses were identified as genogroup II/type 4(GII/4). The genotype distributions of rotaviruses were G2P[4] (48\%), G12P[6] (37\%), G2P[6] (5\%), G9P[8] (5\%), and nontypeable G2 (5\%). Conclusions: This study provides preliminary data on the importance of norovirus and rotavirus as diarrhea etiologic agents in Maldives. A systematic prospective diarrhea surveillance documenting disease burden, etiology, seasonal variation, as well as risk factors should be conducted for the development of public health interventions to reduce diarrhea morbidity and mortality in Maldives. 


\section{Keywords}

\section{Diarrhea, Maldives, Rotavirus, Norovirus}

\section{Introduction}

The Maldives is an archipelago of about 1200 small coral islands in South Asia (Figure 1). The relatively small population of 290,000 people is dispersed over 200 inhabited islands with communities of less than 1000 people. Notwithstanding the enormous human development challenges created by extreme dispersion and fragmentation of the population, the country has, since the 1970s, risen from being one of the world's poorest countries to a middle-income country with leading economic and health indicators in WHO's SEARO region. Many of the island communities are subjected to extreme hardships and vulnerability however, because of the high population density and environmental problems including rising sea levels, fresh water depletion, unsafe waste disposal and non-adapted sewerage systems [1]. Not surprisingly, the Ministry of Health of Maldives has reported diarrheal diseases as one of the important health problems. The incidence reported in 2010 was approximately $10.65 \%$ of the population [2]. While the etiology of diarrhea has been extensively studied in other South or Southeast Asian countries, such data are still lacking for Maldives. The country's unique geography and a high level of tourist traffic and migration could potentially result in different epidemiology than other countries in the region. The purpose of this study was to explore the etiology of acute diarrhea and the antimicrobial susceptibility patterns in Maldives during one diarrhea peak season.

\section{Methodology}

A one-month cross-sectional surveillance study was conducted during the peak diarrhea season in 2007 in Maldives (August-September) to investigate the point-prevalence of acute diarrhea etiologic agents and the antimicrobial susceptibility patterns of bacterial isolates. The study was conducted at the Indira Gandhi Memorial Hospital (IGMH), a central-level hospital in Male, the capital of Maldives; Kulhudhuffushi Regional Hospital (KRH) and Hithadhoo Regional Hospital (HRH), two hospitals in the northern and southern regions of Maldives, respectively (Figure 1 ).

Children aged 3 months to 5 years and adults aged 18 to 70 years with acute diarrhea of less than 72 hours duration and seen as outpatients or inpatients were enrolled in the study after obtaining written informed consent. Acute diarrhea was defined as having three or more unformed stools per 24 hours with at least one additional symptom (nausea, vomiting, abdominal pain, fatigue/lethargy, or fever). One stool sample and clinical and demographic data were collected. Direct stool microscopy and processing of stool samples were performed at the local hospitals. For KRH and HRH, four stool swabs were saved in modified Cary Blair transport media, kept refrigerated and sent to IGMH for culture and identification.

One stool swab was inoculated onto Mac Conkey (MC) agar, Hektoen Enteric (HE) agar, Thiosulfate Citrate Bile salts Sucrose (TCBS) agar, Modified Semisolid Rappaport Vassiliadis (MSRV) agar and enrichment media; Alkaline peptone water (APW), Buffer peptone water (BPW) and Preston and subsequently incubated at $37^{\circ} \mathrm{C}$ for 18 - 24 hours. For secondary culture, APW and BPW were plated on TCBS and MC, and HE and MSRV, respectively. Culture for Campylobacter was performed by primary culture on Modified Charcoal Cefoperazone Deoxycholate Agar (mCCDA) and on Brucella Agar (BA) with sheep blood and secondary culture of Preston enrichment media on mCCDA and on BA with sheep blood after millipore filtration then incubated at $37^{\circ} \mathrm{C}$ under microaerophilic condition for up to 72 hours.

Identification of enteric bacteria including Shigella, Salmonella, Vibrio, Aeromonas, Plesiomonas and Campylobacter was performed by standard biochemical testing [3]. Up to 5 lactose fermenting (Lac+) and 5 nonlactose fermenting ( $\mathrm{Lac}^{-}$) of $E$. coli colonies as identified on $\mathrm{MC}$ agar were saved on Dorset Egg yolk media slant for diarrheagenic $E$. coli identification by DNA hybridization technique. Bacterial isolates were saved on agar slant and sent to the Armed Forces Research Institute of Medical Sciences (AFRIMS), Bangkok, Thailand for confirmation, serotyping and antimicrobial susceptibility testing. Antimicrobial susceptibility testing against ampicillin, azithromycin, ciprofloxacin, erythromycin, nalidixic acid, trimethoprim-sulfamethoxazole, tetracycline, gentamicin and kanamycin was performed by the standard disk-diffusion method using CLSI interpretative 


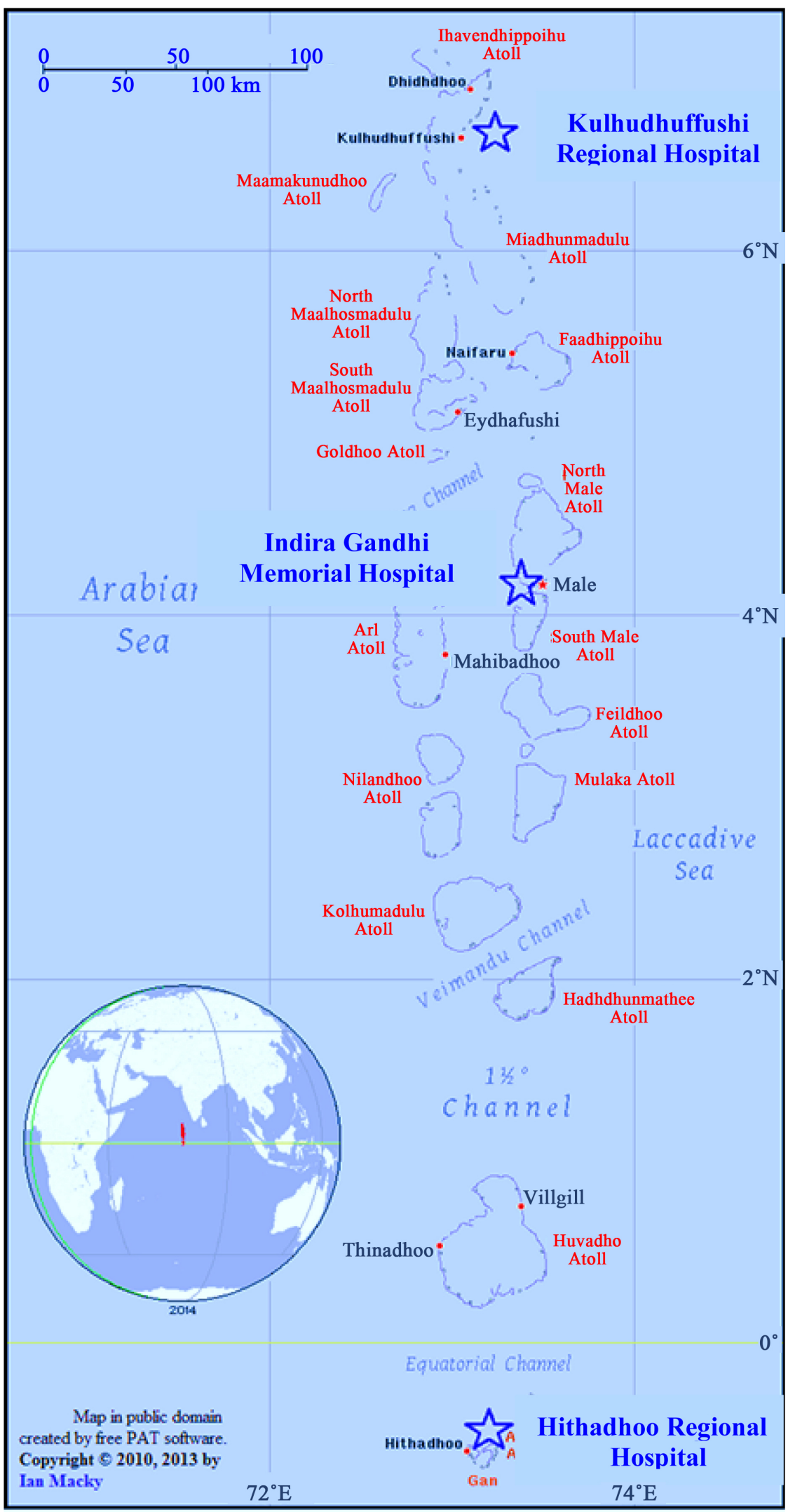

Figure 1. Map of Maldives showing study sites. 
criteria [4].

Aliquots of stool were preserved at $-70^{\circ} \mathrm{C}$ for ELISA and PCR. Rotavirus, astrovirus and adenovirus were identified using EIA test kits (RIDASCREEN ${ }^{\circledR}$, R-Biopharm AG, Darmstadt, Germany). Giardia lamblia and Cryptosporidium were also detected using EIA kits (ProSpecT ${ }^{\mathrm{TM}}$, Remel, Lenexa, Kansas, USA). Norovirus GI and GII was identified by real-time reverse-transcription polymerase chain reaction (RT-PCR) assays [5] [6]. G and P typing of rotavirus and norovirus typing was performed by conventional PCR [7]-[9] anZd sequencing, respectively.

\section{Results}

Stool specimens were collected from 73 children and 57 adults with diarrhea. For children, the median age was 18 months (range 4 - 60 months), and 55\% were male. The mean duration of diarrhea was 24 hrs; 58\%, 68\% and $78 \%$ of the children's guardians reported a history of fever, abdominal pain and vomiting, respectively (Table 1).

Table 1. General characteristic.

\begin{tabular}{|c|c|c|}
\hline & $\begin{array}{c}\text { Children }(\mathrm{N}=73) \\
\mathrm{n}(\%)\end{array}$ & $\begin{array}{c}\text { Adults }(\mathrm{N}=57) \\
\mathrm{n}(\%)\end{array}$ \\
\hline Median age [Range] in months & 18 [4 - 60] months & $35[18$ - 70] years \\
\hline \multicolumn{3}{|l|}{ Age group: } \\
\hline \multicolumn{3}{|l|}{ Children (months) } \\
\hline $3-6$ & $3(4)$ & - \\
\hline $7-12$ & $15(21)$ & - \\
\hline $13-24$ & $38(52)$ & - \\
\hline $25-60$ & $17(23)$ & - \\
\hline \multicolumn{3}{|l|}{ Adults (years) } \\
\hline $18-29$ & - & $21(37)$ \\
\hline $30-49$ & - & $24(42)$ \\
\hline$>50$ & - & $12(21)$ \\
\hline \multicolumn{3}{|l|}{ Gender: } \\
\hline Male & $40(55)$ & $38(67)$ \\
\hline Female & $33(45)$ & $19(33)$ \\
\hline \multicolumn{3}{|l|}{ Case: } \\
\hline Inpatient & $25(34)$ & $16(28)$ \\
\hline Outpatient & $48(66)$ & $41(72)$ \\
\hline \multicolumn{3}{|l|}{ Region: } \\
\hline Male (IGMH) & $25(34)$ & $36(63)$ \\
\hline North (KRH) & $16(22)$ & $8(14)$ \\
\hline South (HRH) & $32(44)$ & $13(23)$ \\
\hline Median duration diarrhea [Range] in hours & $24[1-72]$ & $24[2-72]$ \\
\hline \multicolumn{3}{|l|}{ Stool characteristics: } \\
\hline Watery & $36(49)$ & $32(56)$ \\
\hline Loose & $38(52)$ & $28(49)$ \\
\hline Mucus & $11(15)$ & $9(16)$ \\
\hline Bloody & $1(1)$ & $5(9)$ \\
\hline \multicolumn{3}{|l|}{ Symptoms: } \\
\hline Fever & $42(58)$ & $31(54)$ \\
\hline Abdominal cramps & $42 / 62(68)$ & $48 / 56(86)$ \\
\hline Nausea & 48/70 (69) & $34(60)$ \\
\hline Vomiting & $57(78)$ & $34(60)$ \\
\hline Fatigue & 29/72 (40) & $31(54)$ \\
\hline Used medication before visit & $5(7)$ & $1(2)$ \\
\hline Median body temperature $\left({ }^{\circ} \mathrm{C}\right)$ & $37.2[35.8$ - 39.3] & $37.1[36.1-38.8]$ \\
\hline
\end{tabular}


The most common organisms identified in children were norovirus (43\%), rotavirus (18\%) and Enteropathogenic E. coli (EPEC; 13\%) (Table 2). Rotavirus and norovirus were most commonly found in children aged 1 - 2 years.

For adults, the mean age was 35 years (range 18 - 70 years), and 67\% were male. The median duration ofdiarrhea was 24 hours (range 2 - 72 hours). Patients reported fever (54\%), abdominal pain (86\%), nausea and/or vomiting (60\%) and fatigue (54\%) (Table 1). Vibrio spp. and rotavirus were the most prevalent pathogens, identified in $18 \%$ and $17 \%$ of patient stools, respectively. Out of the 10 Vibrio isolates, nine were identified as Vibrio parahaemolyticus and one as non-O1 and non-O139 V. cholerae, respectively. The other pathogens were Aeromonas (11\%), Salmonella (9\%) and norovirus (8\%) (Table 3). No Shigella, Plesiomonas, Enteroinvasive E. coli (EIEC), Shiga-like Toxin-producing E. coli (STEC) or astrovirus was detected in stools from either children or adults during this period of this study.

Both Vibrio and rotavirus were associated with watery diarrhea in approximately $70 \%$ of the infected patients. Infections with more than one organism were found in $18 \%$ of children and $23 \%$ of adults with diarrhea. No enteric pathogens were identified in $33 \%$ and $46 \%$ of stools from children and adults, respectively.

Among 24 and 31 bacterial isolates obtained from stool culture of children and adults, respectively were tested for antimicrobial susceptibility. Two out of the four Campylobacter isolates were resistant to azithromy-

Table 2. Point-prevalence of pathogens found in child stool specimens, number positive (n) and percent (\%).

\begin{tabular}{lccccccccccccc}
\hline & \multicolumn{3}{c}{ IGMH } & \multicolumn{4}{c}{ KRH } & \multicolumn{3}{c}{ HRH } & \multicolumn{3}{c}{ All sites } \\
\cline { 2 - 11 } & No. tested & $\mathrm{n}$ & $(\%)$ & No. tested & $\mathrm{n}$ & $(\%)$ & No. tested & $\mathrm{n}$ & $(\%)$ & No. tested & $\mathrm{n}$ & $(\%)$ \\
\hline Norovirus & 24 & 6 & $(25)$ & 6 & 2 & $(33)$ & 31 & 18 & $(58)$ & 61 & 26 & $(43)$ \\
Rotavirus & 24 & 11 & $(46)$ & 6 & 0 & $(0)$ & 31 & 0 & $(0)$ & 61 & 11 & $(18)$ \\
Enteropathogenic E. coli (EPEC) & 25 & 0 & $(0)$ & 16 & 4 & $(25)$ & 32 & 4 & $(13)$ & 73 & 8 & $(11)$ \\
Salmonella & 25 & 1 & $(4)$ & 16 & 2 & $(13)$ & 32 & 2 & $(6)$ & 73 & 5 & $(7)$ \\
Enteroaggregative E. coli (EAEC) & 25 & 1 & $(4)$ & 16 & 1 & $(6)$ & 32 & 2 & $(6)$ & 73 & 4 & $(5)$ \\
Aeromonas & 25 & 0 & $(0)$ & 16 & 0 & $(0)$ & 32 & 4 & $(13)$ & 73 & 4 & $(5)$ \\
Enterotoxigenic E. coli (ETEC) & 25 & 1 & $(4)$ & 16 & 0 & $(0)$ & 32 & 1 & $(3)$ & 73 & 2 & $(3)$ \\
Giardia/Cryptosporidium & 24 & 0 & $(0)$ & 6 & 0 & $(0)$ & 31 & 1 & $(3)$ & 61 & 1 & $(2)$ \\
Campylobacter & 25 & 0 & $(0)$ & 16 & 0 & $(0)$ & 32 & 1 & $(3)$ & 73 & 1 & $(1)$ \\
Vibrio & 25 & 0 & $(0)$ & 16 & 0 & $(0)$ & 32 & 1 & $(3)$ & 73 & 1 & $(1)$ \\
No pathogens identified & 25 & 7 & $(28)$ & 16 & 9 & $(56)$ & 32 & 8 & $(25)$ & 73 & 24 & $(33)$ \\
\hline
\end{tabular}

Table 3. Point-prevalence of pathogens found in adult stool specimens, number positive (n) and percent (\%).

\begin{tabular}{|c|c|c|c|c|c|c|c|c|c|c|c|c|}
\hline & \multicolumn{3}{|c|}{ IGMH } & \multicolumn{3}{|c|}{ KRH } & \multicolumn{3}{|c|}{$\mathrm{HRH}$} & \multicolumn{3}{|c|}{ All sites } \\
\hline & No. tested & $\mathrm{n}$ & (\%) & No. tested & $\mathrm{n}$ & $(\%)$ & No. tested & $\mathrm{n}$ & $(\%)$ & No. tested & $\mathrm{n}$ & (\%) \\
\hline Vibrio & 36 & 9 & $(25)$ & 8 & 1 & (13) & 13 & 0 & $(0)$ & 57 & 10 & (18) \\
\hline Rotavirus & 34 & 9 & $(26)$ & 6 & 0 & $(0)$ & 13 & 0 & $(0)$ & 53 & 9 & (17) \\
\hline Aeromonas & 36 & 2 & (6) & 8 & 3 & (38) & 13 & 1 & (8) & 57 & 6 & (11) \\
\hline Salmonella & 36 & 4 & $(11)$ & 8 & 0 & $(0)$ & 13 & 1 & (8) & 57 & 5 & (9) \\
\hline Norovirus & 34 & 1 & (3) & 6 & 0 & $(0)$ & 13 & 3 & (23) & 53 & 4 & (8) \\
\hline Campylobacter & 36 & 2 & (6) & 8 & 0 & $(0)$ & 13 & 1 & $(8)$ & 57 & 3 & (5) \\
\hline Enteropathogenic E. coli (EPEC) & 36 & 1 & (3) & 8 & 1 & (13) & 13 & 0 & $(0)$ & 57 & 2 & (4) \\
\hline Giardia/Cryptosporidium & 34 & 1 & (3) & 6 & 1 & $(17)$ & 13 & 0 & $(0)$ & 53 & 2 & (4) \\
\hline Enterotoxigenic E. coli (ETEC) & 36 & 1 & (3) & 8 & 0 & $(0)$ & 13 & 0 & $(0)$ & 57 & 1 & (2) \\
\hline Enteroaggregative E. coli (EAEC) & 36 & 0 & $(0)$ & 8 & 0 & $(0)$ & 13 & 1 & $(8)$ & 57 & 1 & (2) \\
\hline Adenovirus & 34 & 1 & (3) & 6 & 0 & $(0)$ & 13 & 0 & $(0)$ & 53 & 1 & $(2)$ \\
\hline No pathogens identified & 36 & 15 & $(42)$ & 8 & 4 & (50) & 13 & 7 & (54) & 57 & 26 & (46) \\
\hline
\end{tabular}


cin, ciprofloxacin, erythromycin, nalidixic acid and trimethoprim-sulfamethoxazole. Vibrio spp. isolates were susceptible to all antibiotics except for ampicillin, to which resistance was detected in $82 \%$ of the isolates. One out of two of ETEC isolates was resistant to nalidixic acid. No resistance was detected among non-typhoidal Salmonella isolates. Although only 4/55 (7\%) of all bacterial isolates were found to be resistant to azithromycin, intermediate susceptibility was found in over half of the susceptible strains, in particular, Salmonella (6/19), EPEC (8/19) and EAEC (4/19) (Table 4). More than 90\% of children and adults reported having not taken any medication before presentation to the health facility.

A total of 114 frozen stool specimens from 61 children and 53 adults were available for rotavirus and norovirus detection and genotyping. Rotavirus was detected in 11/61 (18\%) of children and 9/53 (17\%) of adults and 19 out of 20 cases with rotavirus infections were from IGMH in Male. The genotype distribution of the 11 rotavirus detected from children were G2P [4] (46\%), G12P[6] (27\%), G2P[6] (9\%) and G9P [8] (9\%) and non-typeable G2 (9\%). The rotavirus genotype distribution among adults were G2P[4] and G12P[6], with 4/8 (50\%) of each (Table 5). Norovirus was identified in 26/61 (43\%) of children and 4/53 (8\%) of adults with diarrhea from all three sites. All 30 norovirus-positive samples from both children and adults belonged to Genogroup II/type 4 (GII/4).

\section{Discussion}

Our study suggests an important role of viral enteric pathogens, rotavirus and norovirus, as diarrhea etiologic agents in both children and adults in Maldives while bacterial pathogens e.g. V. parahemolyticus played more important role in adults than children. Genotype distribution of norovirus, the most common cause of nonbacterial gastroenteritis outbreaks worldwide, is in agreement with studies conducted in children in western India during 2005-2007, in Bangladesh during 2004-2005 and in Thailand during 2006-2007 in which norovirus GII/4 was predominated and GI was not detected in any of the samples [10]-[12].

Rotavirus is the leading cause of severe diarrhea in children worldwide with most hospitalizations and deaths occurring in children in developing countries in Asia and Africa [13] [14]. In our study, we commonly found rotavirus in children (18\%) and in particular, in adults (17\%). Although rotavirus predominantly affects children

Table 4. Antimicrobial susceptibility pattern of bacterial isolates.

\begin{tabular}{lcccccccccc}
\hline & No. tested & \multicolumn{8}{c}{ Antibiotics number (\%) of resistant isolates } \\
\cline { 3 - 11 } & & Am & Azm & Cip & Na & Sxt & Te & Gm & Km & E \\
\hline Campylobacter & 4 & 0 & $2(50 \%)$ & $2(50 \%)$ & $2(50 \%)$ & $2(50 \%)$ & 0 & 0 & 0 & $2(50 \%)$ \\
Salmonella & 10 & 0 & 0 & 0 & 0 & 0 & 0 & 0 & 0 & - \\
EPEC & 10 & $3(30 \%)$ & $1(10 \%)$ & $1(10 \%)$ & $2(20 \%)$ & $3(30 \%)$ & $2(20 \%)$ & $1(10 \%)$ & 0 & - \\
EAEC & 5 & $3(60 \%)$ & 0 & $1(20 \%)$ & $1(20 \%)$ & $4(80 \%)$ & $1(20 \%)$ & 0 & 0 & - \\
Aeromonas & 13 & $13(100 \%)$ & $1(8 \%)$ & $2(15 \%)$ & $4(31 \%)$ & $3(23 \%)$ & $4(31 \%)$ & $2(15 \%)$ & $2(15 \%)$ & - \\
Vibrio & 11 & $9(82 \%)$ & 0 & 0 & 0 & 0 & 0 & 0 & 0 & - \\
\hline
\end{tabular}

Am: Ampicillin, Azm: Azithromycin, Cip: Ciprofloxacin, Na: Nalidixic acid, Sxt: Trimethoprim-sulfamethoxazole, Te: Tetracyclin, Gm: Gentamicin, Km: Kanamycin, E: Erythromycin.

Table 5. Genotype distribution of rotavirus in children aged $\leq 5$ years and adults with diarrhea in Maldives, August-September 2007 in comparison with other reports from Asia.

\begin{tabular}{|c|c|c|c|c|c|c|c|}
\hline \multirow{2}{*}{ Genotype } & \multicolumn{2}{|c|}{ Children $(\mathrm{n}=11)$} & \multicolumn{2}{|c|}{ Adults $(\mathrm{n}=8)$} & \multicolumn{2}{|c|}{ Total $(\mathrm{n}=19)$} & \multirow{2}{*}{ Prevalence in Asia (Kawai et al., 2012) } \\
\hline & $\mathrm{n}$ & $(\%)$ & $\mathrm{n}$ & $(\%)$ & $\mathrm{n}$ & $(\%)$ & \\
\hline G2P[4] & 5 & $(46)$ & 4 & $(50)$ & 9 & $(48)$ & Common (11.8\%) \\
\hline G2P[6] & 1 & (9) & 0 & (0) & 1 & (5) & Unusual \\
\hline G2 non-typeable & 1 & (9) & 0 & (0) & 1 & (5) & Reported in South East and Southern Asia \\
\hline G9P[8] & 1 & (9) & 0 & (0) & 1 & (5) & Common $(7.4 \%)$ \\
\hline G12P[6] & 3 & $(27)$ & 4 & $(50)$ & 7 & $(37)$ & Unusual. Found in India, Nepal, Sri Lanka. \\
\hline Mixed & 0 & $(0)$ & 0 & $(0)$ & 0 & (0) & Common in Indonesia (23\%), Vietnam (17\%), India (15\%) \\
\hline
\end{tabular}


under 5 years, adults can also be affected as immunity wears off. Adults giving care to children including parents and medical personnel have also been described as being at high risk for rotavirus infections [15] [16]. While studies in Europe and in the United States have documented 2\% - 4\% of rotavirus prevalence in adults presenting with infectious diarrhea [17] [18], much higher rates of $42 \%$ and $63 \%$ have been reported in Indonesia and Mexico, respectively [19] [20].

The most common G and P types of rotavirus that circulated in Asia between 2000 and 2009 were four globally common types: G1P[8], G2P[4], G3P[8] and G9P[8] which were consistent with the finding of the G2P[4] and G9P[8] types in our study. Our study also found an unusual genotype, G12P[6], both in Male as well as in the atolls which have been previously reported especially in South Asian countries [21]-[25]. Moreover, G12 has been reported with increasing frequency over the years in Bangladesh and Nepal [22] [25] [26]. More recent work in Nepal has demonstrated a continued circulation of G12P[6] rotavirus over a period of 2-year that gradually overcame the predominate strains [26]. In this study, approximately $40 \%$ of rotavirus belonged to G12. This may suggest G12 rotavirus has been circulating for multiple years at the time of detection and has become a common genotype in Maldives or it may originally have been introduced from India, Nepal or Bangladesh due to the Maldives' unique geography and its large migrant worker population from these South Asian countries. The emergence of unusual rotavirus types especially in Asia may have an impact on the efficacy of the current rotavirus vaccines [27].

This study has several limitations. First, the point-prevalence study design in three regional hospitals in the Maldives will be able to provide only a snapshot of diarrheal disease etiology and will not represent the situation of the whole country or allow inference to the national level regarding the true prevalence, etiology or seasonality of the pathogens detected. Second, non-stratified convenience sampling may have introduced sampling bias with regard to location, gender and hospital admission status. Third, non-diarrhea controls were not included in this study to document the background carriage of enteric bacteria and viruses in this population. Despite of limitations of the study and resources, this study provides preliminary data on diarrhea etiology and antimicrobial susceptibility pattern in children and adults in the Maldives, a new geographic area of which data is still unavailable. A systematic prospective diarrheal disease surveillance documenting disease burden, etiology, seasonal and geographical variation, as well as risk factors should be initiated if resources permitted.

Application of medical microbiology testing panels to identify bacterial, viral and protozoan/parasitic etiologic agents of diarrheal disease has been challenging in developing countries. Most of those techniques, although are not sophisticated, require laboratory equipment and consumables that are lacking in many laboratories in developing world. Additionally, limited number of knowledgeable or well-trained technicians with a high staff turnover rate has always been a major issue and made sustainability of laboratory capability almost impossible. Despite of these challenges in developing countries where diarrheal disease is the most prevalent whereas health care related resources are limited and prioritized, investigation of diarrhea etiology is still important and should not be neglected. The information may help to achieve the goal of better understanding of diarrheal disease epidemiology and support health policy makers in identifying and implementing the most cost-effective diarrhea prevention and control strategies for reduction of disease morbidity and mortality.

\section{Acknowledgements}

We thank the staff members of the participating hospitals in the Maldives and AFRIMS staffs in Thailand. Funding for this research was provided by the Armed Forces Health Surveillance Center-Global Emerging Infection System (AFHSC-GEIS), Silver Spring, MD, USA.

\section{References}

[1] European External Action Service (2007) The Maldives_European Community Country Strategy Paper 2007-2013. http://eeas.europa.eu/maldives/csp/07_13_en.pdf

[2] Epidemiology and Disease Surveillance Unit, Ministry of Health, Republic of Maldives (2010) Epidemiological Report 1. http://www.health.gov.mv/publications/epi\%20report\%202010.pdf

[3] Isenberg, H.D. (2004) Clinical Microbiology Procedure Handbook. 2nd Edition, ASM Press, Washington DC.

[4] Clinical and Laboratory Standards Institute (2007) Performance Standards for Antimicrobial Susceptibility Testing; Seventeenth Informational Supplement. CLSI Document M100-S17, Clinical and Laboratory Standards Institute, Pennsylvania. 
[5] Kageyama, T., Kojima, S., Shinohara, M., Uchida, K., Fukushi, S., Hoshino, F.B., Takeda, N. and Katayama, K. (2003) Broadly Reactive and Highly Sensitive Assay for Norwalk-Like Viruses Based on Real-Time Quantitative Reverse Transcription-PCR. Journal of Clinical Microbiology, 41, 1548-1557. http://www.ncbi.nlm.nih.gov/pubmed/12682144 http://dx.doi.org/10.1128/JCM.41.4.1548-1557.2003

[6] Vinje, J., Vennema, H., Maunula, L., von Bonsdorff, C.H., Hoehne, M., Schreier, E., Richards, A., Green, J., Brown, D., Beard, S.S., Monroe, S.S., de Bruin, E., Svensson, L. and Koopmans, M.P. (2003) International Collaborative Study to Compare Reverse Transcriptase PCR Assays for Detection and Genotyping of Noroviruses. Journal of Clinical Microbiology, 41, 1423-1433. http://www.ncbi.nlm.nih.gov/pubmed/12682125 http://dx.doi.org/10.1128/jcm.41.4.1423-1433.2003

[7] Gentsch, J.R., Glass, R.I., Woods, P., Gouvea, V., Gorziglia, M., Flores, J., Das, B.K. and Bhan, M.K. (1992) Identification of Group A Rotavirus Gene 4 Types by Polymerase Chain Reaction. Journal of Clinical Microbiology, 30, 1365-1373. http://www.ncbi.nlm.nih.gov/pubmed/1320625

[8] Iturriza-Gomara, M., Kang, G. and Gray, J. (2004) Rotavirus Genotyping: Keeping up with an Evolving Population of Human Rotaviruses. Journal of Clinical Microbiology, 31, 259-265. http://www.ncbi.nlm.nih.gov/pubmed/15494266 http://dx.doi.org/10.1016/j.jcv.2004.04.009

[9] Castello, A.A., Arguelles, M.H., Rota, R.P., Olthoff, A., Jiang, B., Glass, R.I., Gentsch, J.R. and Glikmann, G. (2006) Molecular Epidemiology of Group A Rotavirus Diarrhea among Children in Buenos Aires, Argentina, from 1999 to 2003 and Emergence of the Infrequent Genotype G12. Journal of Clinical Microbiology, 44, 2046-2050.

http://www.ncbi.nlm.nih.gov/pubmed/16757596 http://dx.doi.org/10.1128/JCM.02436-05

[10] Chhabra, P. and Chitambar, S.D. (2008) Norovirus Genotype IIb Associated Acute Gastroenteritis in India. Journal of Clinical Virology, 42, 429-432. http://www.ncbi.nlm.nih.gov/pubmed/18467163 http://dx.doi.org/10.1016/j.jcv.2008.03.014

[11] Dey, S.K., Nguyen, T.A., Phan, T.G., Nishio, O., Salim, A.F., Rahman, M., Yagyu, F., Okitsu, S. and Ushijma, H. (2007) Molecular and Epidemiological Trend of Norovirus Associated Gastroenteritis in Dhaka City, Bangladesh. Journal of Clinical Virology, 40, 218-223. http://www.ncbi.nlm.nih.gov/pubmed/17881286 http://dx.doi.org/10.1016/j.jcv.2007.08.005

[12] Kittigul, L., Pombubpa, K., Taweekate, Y., Yeephoo, T., Khamrin, P. and Ushijima, H. (2009) Molecular Characterization of Rotaviruses, Noroviruses, Sapovirus, and Adenoviruses in Patients with Acute Gastroenteritis in Thailand. Journal of Medical Virology, 81, 345-353. http://www.ncbi.nlm.nih.gov/pubmed/19107961 http://dx.doi.org/10.1002/jmv.21380

[13] Parashar, U.D., Hummelman, E.G., Bresee, J.S., Miller, M.A. and Glass, R.I. (2003) Global Illness and Deaths Caused by Rotavirus Disease in Children. Emerging Infectious Diseases, 9, 565-572. http://dx.doi.org/10.3201/eid0905.020562 http://www.ncbi.nlm.nih.gov/pubmed/12737740

[14] Tate, J.E., Burton, A.H., Boschi-Pinto, C., Steele, A.D., Duque, J. and Parashar, U.D. (2012) 2008 Estimate of Worldwide Rotavirus-Associated Mortality in Children Younger than 5 Years before the Introduction of Universal Rotavirus Vaccination Programmes: A Systematic Review and Meta-Analysis. Lancet Infectious Diseases, 12, 136-141. http://www.ncbi.nlm.nih.gov/pubmed/22030330 http://dx.doi.org/10.1016/S1473-3099(11)70253-5

[15] Wenman, W.M., Hinde, D., Feltham, S. and Gurwith, M. (1979) Rotavirus Infection in Adults. Results of a Prospective Family Study. The New England Journal of Medicine, 301, 303-306. http://www.ncbi.nlm.nih.gov/pubmed/221816

[16] Von Bonsdorff, C.H., Hovi, T., Makela, P., Hovi, L. and Tevalvoto-Aarnio, M. (1976) Rotavirus Associated with Acute Gastroenteritis in Adults. The Lancet, 2, 423. http://www.ncbi.nlm.nih.gov/pubmed/73889

[17] Rubilar-Abreu, E., Hedlund, K.O., Svensson, L. and Mittelholzer, C. (2005) Serotype G9 Rotavirus Infections in Adults in Sweden. Journal of Clinical Microbiology, 43, 1374-1376. http://www.ncbi.nlm.nih.gov/pubmed/15750111 http://dx.doi.org/10.1128/jcm.43.3.1374-1376.2005

[18] Anderson, E.J., Katz, B.Z., Polin, J.A., Reddy, S., Weinrobe, M.H. and Noskin, G.A. (2012) Rotavirus in Adults Requiring Hospitalization. Journal of Infection, 64, 89-95. http://www.ncbi.nlm.nih.gov/pubmed/21939687 http://dx.doi.org/10.1016/j.jinf.2011.09.003

[19] Oyofo, B.A., Subekti, D., Tjaniadi, P., Machpud, N., Komalarini, S., Setiawan, B., Simanjuntak, C., Punjabi, N., Corwin, A.L., Wasfy, M., Campbell, J.R. and Lesmana, M. (2002) Enteropathogens Associated with Acute Diarrhea in Community and Hospital Patients in Jakarta, Indonesia. FEMS Immunology and Medical Microbiology, 34, 139-146. http://www.ncbi.nlm.nih.gov/pubmed/12381465 http://dx.doi.org/10.1111/j.1574-695X.2002.tb00615.x

[20] del Refugio Gonzalez-Losa, M., Polanco-Marin, G.G., Manzano-Cabrera, L. and Puerto-Solis, M. (2001) Acute Gastroenteritis Associated with Rotavirus in Adults. Archives of Medical Research, 32, 164-167. 
http://www.ncbi.nlm.nih.gov/pubmed/11343816 http://dx.doi.org/10.1016/S0188-4409(00)00270-8

[21] Das, S., Varghese, V., Chaudhury, S., Barman, P., Mahapatra, S., Kojima, K., Bhattacharya, S.K., Krishnan, T., Ratho, R.K., Chhotray, G.P., Phukan, A.C., Kobayashi, N. and Naik, T.N. (2003) Emergence of Novel Human Group A Rotavirus G12 Strains in India. Journal of Clinical Microbiology, 41, 2760-2762. http://www.ncbi.nlm.nih.gov/pubmed/12791925 http://dx.doi.org/10.1128/jcm.41.6.2760-2762.2003

[22] Rahman, M., Sultana, R., Ahmed, G., Nahar, S., Hassan, Z.M., Saiada, F., Podder, G., Faruque, A.S., Siddique, A.K., Sack, D.A., Matthijnssens, J., Van Ranst, M. and Azim, T. (2007) Prevalence of G2P[4] and G12P[6] Rotavirus, Bangladesh. Emerging Infectious Diseases, 13, 18-24. http://www.ncbi.nlm.nih.gov/pubmed/17370511 http://dx.doi.org/10.3201/eid1301.060910

[23] Alam, M.M., Malik, S.A., Shaukat, S., Naeem, A., Sharif, S., Angez, M., Rana, M.S., Khurshid, A. and Zaidi, S.Z. (2009) Genetic Characterization of Rotavirus Subtypes in Pakistan-First Report of G12 Genotype from Pakistan under WHO-Eastern Mediterranean Region. Virus Research, 144, 280-284. http://www.ncbi.nlm.nih.gov/pubmed/19720243 http://dx.doi.org/10.1016/j.virusres.2009.03.015

[24] Ahmed, K., Batuwanthudawe, R., Chandrasena, T.G., Mitui, M.T., Rajindrajith, S., Galagoda, G., Pun, S.B., Uchida, R., Kunii, O., Moji, K., Abeysinghe, N., Nishizono, A. and Nakagomi, O. (2010) Rotavirus Infections with Multiple Emerging Genotypes in Sri Lanka. Archives of Virology, 155, 71-75. http://www.ncbi.nlm.nih.gov/pubmed/19921392 http://dx.doi.org/10.1007/s00705-009-0552-0

[25] Sherchand, J.B., Nakagomi, O., Dove, W., Nakagomi, T., Yokoo, M., Pandey, B.D., Cuevas, L.E., Hart, C.A. and Cunliffe, N.A. (2009) Molecular Epidemiology of Rotavirus Diarrhea among Children Aged <5 Years in Nepal: Predominance of Emergent G12 Strains during 2 Years. The Journal of Infectious Diseases, 200, S182-S187. http://www.ncbi.nlm.nih.gov/pubmed/19817599 http://dx.doi.org/10.1086/605046

[26] Gauchan, P., Nakagomi, T., Sherchand, J.B., Yokoo, M., Pandey, B.D., Cunliffe, N.A. and Nakagomi, O. (2013) Continued Circulation of G12P[6] Rotaviruses over 28 Months in Nepal: Successive Replacement of Predominant Strains. Tropical Medicine and Health, 41, 7-12. http://www.ncbi.nlm.nih.gov/pubmed/23533063 http://dx.doi.org/10.2149/tmh.2012-28

[27] Kawai, K., O’Brien, M.A., Goveia, M.G., Mast, T.C. and El Khoury, A.C. (2012) Burden of Rotavirus Gastroenteritis and Distribution of Rotavirus Strains in Asia: A Systematic Review. Vaccine, 30, 1244-1254.

http://www.ncbi.nlm.nih.gov/pubmed/22212128 http://dx.doi.org/10.1016/j.vaccine.2011.12.092 